\title{
COMMENTS
}

\section{THE STATUS OF FOREIGN GORPORATIONS: EFFECT GIVEN "EQUAL TREATMENT" STATUTES}

\section{The Constitutional Setring}

$\mathbf{T}$ HE HISTORY of foreign corporation law reveals the effects of two opposing theories rooted in divergent conceptions of the nature of corporations. The restrictive theory emphasizes the high nature of the act of sovereignty by which a corporate franchise is granted and denies the existence of corporations beyond the boundaries of the creating jurisdiction. The liberal theory views the corporation as a normal business instrumentality whose legal personality is no more than a convenient mechanism of commerce and industry. Under this latter conception, foreign corporations are accorded positions of approximate equality with domestic corporations. ${ }^{1}$

In broad outline, foreign corporation law in America has evolved gradually from the rigidity of the restrictive theory to the equality of the liberal theory. The law's early development, however, was not the result of a logically formulated theory of the extraterritorial status of the corporation. ${ }^{2}$ Corporations in colonial times were predominantly expansive trading companies, identified with the grant of special privilege; monopoly, not legal personality, was their distinguishing feature.

The thought and language of the monopolistic period persisted in the early nineteenth century, and incorporation by special act of the legislature continued to be the practice. Changes brought about by an extraordinary expansion of corporate activity, however, inveighed heavily against the restrictive theory, ${ }^{3}$ and in 1809 recognition of the rights of corporations to sue in courts of states other than the state of incorporation $^{4}$ struck down a frst principle of restrictivism, the nonrecognition of artificial personalities created by foreign sovereigns.

Nevertheless, the right of a corporation to transact business within another state was asserted less successfully. In Bank of Augusta v. Earle, ${ }^{5} \mathrm{Mr}$. Chief Justice Taney, grasping the logical completeness of

\footnotetext{
${ }^{2}$ Henderson, The Position of Foreign Corporations in American Constitutional Law, in 2 HaRVARD StUdies IN JURISPRUdence 3-6 (1918).

${ }^{2} I d$. at 34 . ${ }^{3} I d$. at $36-37$.

- Bank of United States v. Deveaux, 9 U.S. (5 Cranch) 37 (1809).

${ }_{3}^{8} 8$ U.S. (1 3 Pet.) 443 ( 1839 ).
} 
restrictivism as a juristic conception, announced three closely reasoned dicta that infuenced the development of the law of foreign corporations for at least a half century and, in some measure, continue to influence related judicial thought to this day: ${ }^{6}$

(I) The protection of the privileges and immunities clause of the Constitution does not extend to foreign corporations;

(2) A corporation has no existence beyond the boundaries of the creating state; and

(3) The state has unrestrained constitutional power to refuse recognition to a foreign corporation and to exclude it from transacting business within its boundaries. ${ }^{\top}$

The effect of denying foreign corporations the protection of the privileges and immunities clause is to permit a state to withhold from foreign corporations those privileges that it confers on domestic corporations. To require that a state admit all foreign corporations doing a particular business simply because it had chartered a similar domestic corporation was unthinkable in this period in which corporations were regarded with suspicion. For a state to be unable to. limit the number of corporations doing business therein may today be an unacceptable proposition. Thus, a corporation is not a "citizen" within the meaning of the privileges and immunities clause. ${ }^{8}$ By separate constitutional development, however, a foreign corporation may resort to local courts ${ }^{9}$ and engage in interstate and foreign commerce. ${ }^{10}$

Taney's second dictum was a concession to the theory of the nonexistence of the corporation beyond the boundaries of the creating state. The Court had adhered to this theory earlier in holding that jurisdiction could be obtained over a corporation only in the state of incorporation. ${ }^{11}$ The expansion of corporate activity required so restrictive a holding to be circumvented, and thus the theories of "presence" and "implied consent" evolved. A state in which a foreign corporation was "doing business" could assume jurisdiction over the corporation by resorting

'Id. at 502-13.

${ }^{7}$ Henderson, op. cit. supra note $I$, at $48-49$.

${ }^{8}$ For the observation that an argument can forcibly be made that the privileges and immunities clause should not be wholly inapplicable to corporations and for a collection of precedent to the contrary in spite of the argument's plausibility, see Holt, Full Faith and Credit-A Suggested Approach to the Problem of Recognition of Foreign Corporations, 89 U. PA. L. Rev. 453, 454 (1941).

${ }^{\circ}$ Bank of United States v. Deveaux, 9 U.S. (5 Cranch) 37 (1809).

${ }_{20} 3$ AM. Jur. Foreign Corporations $\$ 39$ (1939).

${ }^{12}$ Bank of Augusta v. Earle, 38 U.S. (13 Pet.) 443 (1839). 
to these theories and still do no violence to existing notions of due process. These tests of jurisdiction have in turn been replaced, and the substituted approach is the "fairness" or "minimum contacts" test. ${ }^{12}$ Thus, the dictum that corporations do not exist beyond the boundaries of the creating state has run its course, but not without significantly affecting the development of foreign corporation law.

The third of Taney's important dicta was that a state has unrestrained constitutional power to refuse recognition to a foreign corporation and to exclude it from transacting business within the state's boundaries. Even after the adoption of the fourteenth amendment, many decisions dogmatically expounded this essence of restrictive theory. As late as $1906^{13}$ the Supreme Court was stating restrictivism in its most drastic form: A state might decline to admit a foreign corporation arbitrarily or for a motive quite contrary to the general purpose of the Constitution; a state might admit a corporation on conditions that result in discrimination between it and domestic corporations, and even between it and corporations of other states; and a state might admit a corporation on one set of conditions and then, without cause, impose a more burdensome set. ${ }^{14}$

In a series of decisions beginning in $1910{ }^{15}$ the Supreme Court imposed three important qualifications upon state powers of exclusion and expulsion, amounting to almost complete repudiation of restrictivism:

(I) The admission of a foreign corporation cannot be subject to "unconstitutional conditions";

(2) A foreign corporation, as a person, is to be protected against arbitrary expulsion by the due process clause of the fourteenth amendment; and

(3) A foreign corporation is entitled to equality of treatment with domestic corporations under the fourth clause of the fourteenth amendment.

Thus, the states may not employ their broad powers over foreign corporations to attain unconstitutional ends. Limitations upon state

${ }^{19}$ Note, Jurisdiction Over Foreign Corporations: The North Carolina Statute, 1959 DukE L.J. 644, 645 n. 5. The note, generally, reviews three North Carolina Supreme Court decisions respecting the application of North Carolina's innovating statutory provision, N.C. GEN. STAT. $§ 55-145(a)(3)$ ( 1960$)$, extending the jurisdiction of its courts over foreign corporations in accordance with the Supreme Court's decision in International Shoe Co. v. Washington, 326 U.S. 310 (1945).

${ }^{13}$ National Council U.A.M. v. State Council, 203 U.S. 151 (1906).

"Henderson, op. cit. suppra note 1 , at I 10-1 1 .

${ }^{16} I d$. at $\mathrm{III}$. 
power to impose conditions, to regulate and to expel are now recognized as inherent in the boundaries of state jurisdictional authority, in the provisions of state and federal constitutions and in principles of natural law. What remains of the power to exclude may yet vanish with a complete recognition of the states' full faith and credit obligation. ${ }^{10}$ In substance, this is the current constitutional setting of foreign corporation law.

\section{The "Equal Treatment" Provisions}

In the gradual evolution of foreign corporation theory from the extremely restrictive to the liberal, there emerged in more than half the states constitutional and statutory provisions which, while varying in wording, explicitly or inferentially make state corporation law applicable to foreign corporations. ${ }^{1 i}$ The Illinois statute, which is sufficiently representative, has language that is unambiguous on its face. ${ }^{18} \mathrm{~A}$

${ }^{10}$ Holt, supra note 8 , at 480 .

${ }^{27}$ Those provisions in which the legislature has expressly granted pure equal treatment are: Alaska Comp. Laws ANN. $\${ }_{36-2 A-142}$ (Supp. 1958); Colo. Rev. Stat. ANN. § 3 1-10-2 (Supp. 1957); D.C. Code ANN. § 29-933 (Supp. x 957); FLA. STAT. ANN. $\S 613.02$ (1956); HawaII Rev. Laws $\S 174-8$ (1955); IDaho Code ANN. $\S$ 30-510 (x948); Ill. ANn. STAT. ch. 32, § 157.103 (Smith-Hurd 1954); Iowa CODE ANN. § 494.I4 (x949); LA. Rev. Stat. § I $2: 203$ (x950); Mich. Comp. Laws $\S 450.94$ (Supp. 1956); Minn. Stat. Ann. $\$ 303.09$ (1947); Miss. Code Ann. $\S 534$ (1957); Mo. ANn. Stat. $\$ 351.575$ (1952); Mont. Rev. Codes ANn. \& 15-1709 (1955); N.M. Stat. ANN. \& 51-10-1 (1953); N.C. Gen. STAT. \$ 55-132 (x960); N.D. Rev. Code $\S$ x0-2202 (Supp. 1957); OkLa. Stat. Ann. tit. 18, § I.199 (1953); ORE. Rev. Stat. $\$ 57.660$ (Supp. 1959); PA. Stat. AnN. tit. 15, $\S 2852-909$ (1958); S.D. CODE § II-2101 (1939); TENN. CODE ANN. $\$ 48-907$ (x955); Tex. Rev. Civ. Stat. ANn. art. 1532 (x945); W. VA. Code ANv. § $309 x$ [79] (1955); WIs. STAT. $§$ i 80.807 (x957). In other states the legislative expression has taken the form of substantial equal treatment as seen through the following: ARIZ. REV. STAT. ANn. $\$$ 10-484 (1956); ARK. CONST. art. I2, § xI; CAL. Const. art. I2, § 15; GA. Code AnN. § 22-1502 (1936); IND. Ann. Stat. § 25-302 (1948); Kan. Gen. Stat. ANN. § 17-505 (1949); Kr. Const. § 202; ME. Rev. Stat. ANn. ch. 53, § 229 (x954); MD. ANN. CODE art. $23, \S 88$ (1957); MAss. ANN. LAws ch. I8x, $\$ 2$ (1955); Ohio Rev. CODE ANN. $\$ \times 703.15$ (Page 1954); R.I. GEN. LAws ANN. $\$ 7-2-26$ (1956); S.C. CODE $\S \times 2-701$ (I952); Utah Const. art. $x 2, \S 6$; VT. STAT. ANí. tit. I1, $\S 762$ (1958); VA. CoNST. art. I2, $\S 163$; WASH. CoNsT. art. I2, $\S 7$. States lacking definite legislative expression are Alabama, Connecticut, Delaware, Nebraska, Nevada, New Hampshire, New Jersey, New York, and Wyoming. Some of the lastmentioned states rest their treatment of foreign corporations on a system of comity,

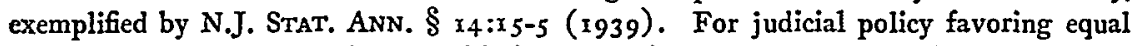
treatment in the absence of any legislative expression, see German-American Coffee Co. iv. Diehl, 216 N.Y. 57 , 109 N.E. 875 (1915).

18 "No foreign corporation shall transact in this State any business which a corporation organized under the laws of this State is not permitted to transact. $A$ Foreign 
foreign corporation "shall ... enjoy the same ... rights and privileges as a domestic corporation" and "shall be subject to the same duties, restrictions, penalties, and liabilities."10 To the extent that provisions in other jurisdictions are less specific, liberal constructions, perhaps even strained interpretations, may be necessary if local corporation law is to be similarly applied. ${ }^{20}$ But, whether the legislature has expressed itself specifically or subtly, equality of treatment is unquestionably its purpose. An examination of the judicial effect given these equal treatment provisions in several pronounced areas of corporate affairs will illuminate the practical status of the foreign corporation under the law.

\section{Taxation}

Insofar as a foreign corporation is engaged in interstate or foreign commerce or is incorporated by the federal government, it has the righit to pursue business in a jurisdiction other than that of its origin. Within the constitutional limits outlined above, ${ }^{21}$ however, a state may prescribe the terms upon which foreign corporations not similarly engaged may be admitted to do business. Accordingly, a state may require the payment of arbitrary fees, or it may at stated intervals exact "graduated privilege taxes" based upon the amount of business transacted within the state. ${ }^{22}$

corporation which shall have received a certificate of authority under this Act shall, until a certificate of revocation or of withdrawal shall have been issued as provided in this Act, enjoy the same, but zo greater, rights and privileges as a domestic comporation organized for the purposes set forth in the application pursuant to which such certificate of authority is issued; and, except as in this Act otherwise provided, shall be stebject to the same duties, restrictions, penalties, and liabilities now or hereafter imposed upon a domestic corporation of like character." ILL. ANN. STAT. ch. 32, § 157.103 (SmithHurd 1954). (Emphasis added.)

${ }^{10}$ The Illinois Supreme Court has construed this provision in the following language: "While the act does not declare foreign corporations complying with its terms to be domestic corporations nor purport to adopt the foreign corporations, it does clothe foreign corporations with the same powers, rights, and privileges and imposes upon them the same liabilities and duties as domestic corporations. There is essentially no difference between the foreign and domestic corporation. The intention was to obliterate any distinction in the treatment of domestic corporations and foreign corporations which had complied with the act. The effect was to give the foreign corporation the same standing in the eye of the law as the domestic corporation, giving it the same rights and subjecting it to the same remedies." Charles Friend \& Co. v. Goldsmith \& Seidel Co., 307 IIl. 45, 53-54, 138 N.E. 185 , 188 (1923). See AM. JuR. Foreign Corporations $\$ 314$ n.19 (1939).

${ }^{30}$ Latty, Pseatdo-Foreign Corporations, 65 YALE L.J. 137, 157 (1955).

${ }^{21}$ But see Holt, supra note 8 , for the requirements a recognition of the states' full faith and credit obligation would impose.

${ }^{29}$ State ex rel. Davenport v. International Harvester Co., 216 Ind. $463,469,25$ 
The Supreme Court has held that when a corporation is granted permission to enter a state having an equal treatment provision, the corporation acquires a contractual right to do business in that state. ${ }^{23}$ Any financial conditions imposed by the state become elements of this contract. However, the corporation is subject to no greater liabilities than were contemporaneously or may be subsequently imposed upon domestic corporations. ${ }^{24}$ Thus, although the corporation may be required to bear its proportionate share of the burdens of government, these burdens are to be imposed without discrimination. ${ }^{25}$

An examination of state taxation policy reveals that the incidence of taxes on domestic corporations will extend, within constitutional limits, to foreign corporations. For example, an ad valorem tax is imposed indiscriminately on the property of both domestic and foreign corporations. $^{26}$ In order to impose on domestic corporations engaged in both interstate and intrastate commerce the same state income tax that is imposed on similarly engaged foreign corporations, some jurisdiction $\mathrm{s}^{27}$ have limited the base of the tax to that portion of income derived from interstate commerce attributable to business done in the state, although they have the power to tax the entire net income of a domestic corporation from whatever source derived. ${ }^{28}$

N.E.2d 242, 245 (1940); accord, Hanover Fire Ins. Co. v. Harding, 272 U.S. 494 (1926).

${ }^{33}$ The statute amounts to a contract with complying foreign corporations that they will not be subjected during the period for which they are admitted to greater liabilities than those imposed on domestic corporations, and subsequent statutes imposing higher annual license fees on foreign corporations for the privilege of continuing to do business are void as impairing the obligation of such contract. American Smelting \& Ref. Co. v. Colorado ex rel. Lindsley, 204 U.S. 103 (1907); accord, American Can Co. v. Emmerson, 288 Ill. 289, 123 N.E. 581 (1919). This rationale was not followed, however, and equal treatment was denied in British-American Mortgage Co. v. Jones, 77 S.C. $443,5^{8}$ S.E. $417(1907)$, where it was held that each year the license of the foreign corporation expired and was renewed only by the payment of the annual license fee. Thus, the contract with the state for equal treatment was limited to one year, and accordingly, additional conditions could be perennially imposed.

${ }^{34} 23$ AM. JUR. Foreigiz Corporations $§ 322$ (1939).

${ }^{25}$ State ex rel. Davenport v. International Harvester Co., 216 Ind. $463,469,25$ N.E.2d 242, 245 (1940).

${ }^{30}$ McDaniel v. Texarkana Cooperage \& Mfg. Co., 94 Ark. 235, 126 S.W. 727 (xgro). Accord, Gray v. Central Fla. Lumber Co., ro4 Fla. 446, I 40 So. 320 , cert. detried, 287 U.S. 634 (1932).

${ }^{27}$ E.g., Matson Nav. Co. v. State Bd. of Equalization, 3 Cal.2d I, 43 P.2d 805 (1935), aff'd, 297 U.S. 441 (1936). Thus, equal treatment is still the effect, although the legislative concern is clearly with the domestic corporation.

${ }^{23}$ For possible exceptions to this power to tax, see Lynch v. New York ex rel. Pierson, 293 U.S. 52 (1934). 
The cases indicate that courts have made a studied effort to treat foreign and domestic corporations on the planes of equality set by the legislatures. When a licensing fee has been exacted in different terms for the two classes of corporations, courts, for constitutional reasons, ${ }^{20}$ have made certain that the legislation results in equality of treatment and is "in substance and effect" the same for both classes. ${ }^{30}$

In spite of the elementary equal treatment proposition, instances of judicial discrimination in taxation have been glaring. These have resulted from both unjustified classification and undeserved exemption. For example, a Minnesota statute grants properly licensed foreign corporations the same rights and privileges enjoyed by domestic corporations. Nevertheless, a foreign corporation must procure the twohundred-dollar "fur buyer's license" prescribed for nonresidents, rather than the five-dollar license for residents. ${ }^{31}$ Even though the nonresident corporation is duly licensed in the state, the Minnesota court held that its status as a "nonresident corporation" does not change. The equal treatment statute does not grant foreign corporations "immunity from licensing or taxation on a basis or classification different from that applied to domestic corporations in cases where the fact of residence or nonresidence is a valid distinguishing element of the classification," and fur-buying, which would seem quite apart from wildlife-taking, the regulation of which is admittedly within the police power, is such a case. Nor does this result make the licensing act "inconsistent with" the corporation act, which, the court broadly describes, "is designed to protect society's dealings with businesses conducted in corporate form." The design of the equal treatment statute is conveniently lost. ${ }^{32}$

A second instance of discrimination involved a charitable foreign corporation that was denied an exemption from a local inheritance tax, although if it had been a domestic corporation, "there could be no doubt as to its right of exemption." Notwithstanding statutory provision that foreign corporations shall have the same rights and privileges as domestic corporations, the Illinois court stated that "the rule of construction accepted by this court is that an act of the legislature granting powers, privileges, or immunities to corporations must be held to apply only to corporations created under the authority of this state, and over

\footnotetext{
${ }^{20}$ Great W. Sugar Co. v. Mitchell, x I9 Mont. 328, 338, x 74 P.2d 817, 822 (1946).

${ }^{\text {so }}$ American Smelting \& Ref. Co. v. Colorado ex rel. Lindsley, 204 U.S. 103 (x907).

${ }^{32}$ State ex rel. Ohsman \& Sons Co. v. Starkweather, 214 Minn. 232, 7 N.W.2d $747(x 943)$.

${ }^{32}$ Id. at 237,7 N.W.2d at 749 .
} 
which this state has the power of visitation and control, unless the intent that the act shall apply to other than domestic corporations is plainly expressed in the terms of the act."33

In the Minnesota case the label "nonresident" permitted the exaction from the foreign corporation of a licensing fee forty times greater than the fee required of domestic corporations; in the Illinois case "strict construction" of the exemption provisions of a tax statute resulted in the taxation of an admittedly charitable, but still foreign, corporation. These results, again, were sanctioned by courts that were aware of the equal treatment statutes but insufficiently constrained to follow them when matters of state revenue were in question.

\section{Legal Actions}

Apart from specific questions of jurisdiction involving attachment, service of process and venue, the general proposition is that a corporation that complies with the state's statutory requirements has the right to sue or defend in a jurisdiction other than that of its origin. ${ }^{34}$ In the face of equal treatment provisions, absent positive statutory qualification, this right of access which rests on the comity of states $^{3 \tilde{5}}$ should, as with domestic corporations, be absolute.

\section{A. Amenability to Attachment and Process}

Courts that are conscious of equal treatment requirements have generally adhered to the principle that foreign corporations are to be subject to suit in the same manner that is prescribed for suits against domestic corporations of like character. ${ }^{36} \mathrm{~A}$ foreign corporation is subject to the same liabilities as domestic corporations and is, therefore, subject to suit in that state. This is true even though the corporation is not required to designate an agent upon whom process could be served. ${ }^{37}$

A foreign corporation that has agents in a state, who are authorized and designated by statute to receive service, must be sued in personam; ${ }^{38}$

${ }^{a a}$ People v. Woman's Home Missionary Soc'y, 303 Ill. 4 1 8, 420-2 I, 135 N.E. 749, 750 (1922).

3t Bank of United States v. Deveaux, 9 U.S. (5 Cranch) 37 (1809); accord, Heart of America Ins. Agency v. Wichita Cab \& Transp. Co., I5I Kan. 420, 99 P.2d 765 (1940).

${ }_{23}{ }_{23}$ AM. JUR. Foreign Corporations $\S_{4} 8_{4}$ (1939); Taylor v. Toledo Trust Co., 119 Fla. 90, 160 So. 366 (1935).

${ }^{30}$ Jennings v. Idaho Ry., Light \& Power Co., 26 Idaho 703, I46 Pac. Ior (1915).

${ }^{37}$ International Union of Mine, Mill \& Smelter Workers v. Tennessee Copper Co., 3 I F. Supp. 1015 (E.D. Tenn. 1940).

${ }^{38}$ While the foreign corporation is not a resident of the state, suit must be commenced 
its property, like that of domestic corporations, cannot be attached. ${ }^{30}$ Likewise, a creditor's failure to attach corporate property is not available to a foreign corporation as a defense. ${ }^{40}$ This is, of course, conformable with the rule of federal jurisdiction that a foreign corporation is regarded as a citizen or resident of the state of its incorporation. ${ }^{41}$

Statutes that confer greater rights on foreign corporations than on domestic corporations are carefully scrutinized by the courts and, in instances, invalidated for want of due process. Thus, it is unconstitutional to provide for service of process upon the secretary of state for domestic corporations that have not designated agents to receive service when foreign corporations can be served through a state official only upon affidavit and court order." Such discrimination is as incompatible with the requirements of equal treatment as it is offensive to notions of due process.

\section{B. Propriety of Local Venue}

In states that give equal treatment, absent qualifying statutory provisions, it is not enough that venue statutes do not unreasonably discriminate against foreign corporations, ${ }^{43}$ although this may satisfy a circumscriptive fourteenth amendment. For purposes of venue, foreign corporations permitted to exercise corporate functions within the state must be treated as domestic corporations. This principle has received consistent recognition. Complying corporations have been held to have acquired both the right to sue and to be sued in the courts of a state. ${ }^{44}$ One state, ${ }^{45}$ however, which at first gave equal treatment by denying to a domestic corporation a change of venue in view of a prior

by personal service upon its agents. Sinclair Ref. Co. v. Bounds, 198 Ark. 149, 127 S.W.2d 629 ( r939).

${ }^{39}$ Burgin Bros. \& McCane v. Barker Baking Co., 152 La. 1075, 95 So. 227 (1922); Charles Friend \& Co. v. Goldsmith \& Seidel Co., 307 Ill. 45, 138 N.E. 185 (x923). ${ }^{10}$ Palmer v. Avalon Oil Co., ro La. App. 512, 120 So. 78x (1929).

${ }^{41} 72$ Stat. 415,28 U.S.C. $\$ 1332$ (c) (1958). See generally 23 AM. Jur. Foreign Corporations \& 502 (I939). ( $(1942)$.

"2 Bruhnke v. Golden W. Wineries Inc, 56 Cal. App. 2d Supp. 943, I32 P.2d 102

${ }^{13}$ An example is the statute that makes foreign corporaions subject to suit in any county in the state, while providing that domestic corporations shall be sued only in the counties where they are found, or do business or have a representative. See 23 AM. Jur. Forcign Corporations § 503 n.5 (1939).

"Smith-Douglass Co. v. Honeycutt, 204 N.C. 219,167 S.E. 810 (I933); accord, John P. Nutt Corp. v. Southern Ry., 214 N.C. 19, 197.S.E. 534 (1938), and Hill v. Atlantic Greyhound Corp., 229 N.C. 728, 5 I S.E.2d 183 (1949).

${ }^{15}$ Smith v. Inter-Mountain Auto. Co., 25 Idaho 212, 136 Pac. I125 (1913). 
holding $^{48}$ - that foreign corporations acquired no fixed residence, later refúsed to extend subsequently enacted venue provisions respecting domestic corporations to a foreign corporation. ${ }^{47}$

\section{Pleading the Statute of Limitations}

Although a few courts have held that a foreign corporation cannot plead the statute of limitations as a defense in actions against it, ${ }^{48}$ general practice allows the defense if the corporation may be served with process in the forum state. ${ }^{40}$ Compliance by a foreign corporation with constitutional or statutory requirements will start the statute of limitations running against it, as well as in its favor..$^{50}$ In brief, the statute of limitations is no exception to the statutes applicable to a complying corporation.

\section{Corporation Finance}

\section{A. Issuance of Stock}

The issuance of stock by a corporation, like the election of officers, ${ }^{\text {si }}$ the payment of dividends, ${ }^{59}$ the inspection of books ${ }^{53}$ and the naming of the corporation, ${ }^{54}$ is regarded as involving the internal affairs of the corporation over which, as a general rule, courts of a nonincorporating state will not assume jurisdiction. ${ }^{5 \overline{5}}$ Although in isolated instances state courts have exercised ${ }^{56}$ jurisdiction over foreign corporations to compel the issuance of stock, in construing, in the light of equal treatment requirements, a statute that makes no express distinction between foreign and domestic corporations, ${ }^{57}$ these cases have been rejected as authority

\footnotetext{
${ }^{60}$ Boyer v. Northern Pac. Ry., 8 Idaho 74, 66 Pac. 826 (190x).

${ }^{17}$ American Sur. Co. v. District Court, 43 Idaho 589, 254 Pac. 515 (19.27).

${ }^{68}$ The rule adopted to sauction this result is that a foreign corporation is deemed to come within saving clauses of statutes of limitation relative to persons absent from the state.

${ }^{80}$ Weishaar v. Butters Pump \& Equip. Co., 149 Kan. 842, 89 P.2d 864 (1939). See 23 Am. Jur. Foreign Corporations $\$ 562$ (1939).

${ }^{80}$ American Sur. Co. v. Blake, 45 Idahio 159, 26I Pac. 239 (1927).

${ }^{22}$ $3_{3}$ AM. JUR. Foreign Corporations $\$ 43 \mathrm{I}$ (1939).

${ }_{23}$ AM. JUR. Foreign Corporations $\$ 434$ (1939).

${ }_{23}{ }_{23}$ AM. JUR. Foreign Corporations $\$ 435$ (x939).

${ }^{54}$ Red Seal Ref. Co. v. Red Seal Ref. Cor̀p., x15 Okla. 63, $24 \times$ Pac. 762 (1925); State ex rel. Equitable Sec. Corp. v. Conway, x89 La. 272, I79 So. 312 (1938).

${ }^{56}{ }_{23}$ AM. JUR, Foreign Corporations $\$ 424$ (1939).

${ }^{80}$ The term "exercised" is used, since considerations are of policy and propriety rather than of power.

"In Guilford v. Western Union Tel. Co., 59 Minn. 332, 6x N.W. 324 (1894), jurisdiction was exercised to compel the issuance of stock to a Minnesota citizen in lieu of a pre-existing certificate which had been lost.
} 
that a foreign corporation can issue capital stock outside the state of its incorporation. ${ }^{58}$ Courts recognize that the term "internal affairs" is more or less indefinite, but as to whether the issuance of stock by a corporation may be so designated, they confront no problem. "From the very nature of corporate stock, which is created by and under the authority of a state, the right or duty to issue it, like the other attributes of the corporation, is governed by the local laws of the state from which it derives its existence, and not by that of any other state." ${ }^{\text {No }}$ The excepting label "internal affairs" represents a body of law too substantial and a policy so acceptable that contrary results, even in the face of the literal requirements of equal treatment, cannot be expected. ${ }^{.0}$

\section{B. Restrictions on Investments}

In equal treatment states, local statutes regulating investments that may be held by certain domestic corporations should apply to foreign corporations of like character. A conveyance of real estate to a foreign corporation organized for educational or benevolent purposes, therefore, has not been presumed to be against state policy if similar domestic corporations are allowed to take title to real estate. ${ }^{.1}$ On the other hand, an investment by a foreign corporation that constituted the controlling interest in a competing domestic corporation has been disallowed as contrary to the state's policy against monopolies. ${ }^{02}$ Although courts have consistently given equal treatment in this area, harsh results have been worked, as where a foreign corporation expressly licensed to do a general brokerage and commission business was subsequently and, for all purposes, permanently precluded from buying, selling or dealing in corporate securities on the sole ground that domestic corporations were not authorized to hold stock in other corporations. ${ }^{03}$

\section{Corporate Claims}

Since equal treatment statutes do not permit foreign corporations to transact business denied to domestic corporations, it follows that foreign corporations cannot be accorded greater privileges than domestic

\footnotetext{
${ }^{88}$ Southern Sierras Power Co. v. Railroad Comm'n, 205 Cal. 479, 271 Pac. 747 (1928).

${ }^{58}$ Id. at 483,271 Pac. at $748-49$.

${ }^{\circ 0}$ Fox-Woodsum Lumber Co. v. Bank of America Nat'l Trust \& Sav. Ass'n, 7 Cal.2d 14, 59 P.2d Iorg (1936).

${ }_{02} 3$ AM. JUR. Foreign Corporations \& 173 (1939).

ez Dunbar v. American Tel. \& Tel. Co., 238 Ill. 456, 87 N.E. 52 I (1909).

${ }^{03}$ Golden v. Cervenka, 278 Ill. 409, 116 N.E. 273 (1917).
} 
corporations in making contracts within an equal treatment state. ${ }^{64}$ Thus, foreign corporations have been subject to the defense of usury when asserted by resident defendants, even though the contract rate of interest was usurious only in the resident's state and not in the state of incorporation. ${ }^{65}$ Equal treatment has been applied in the reverse situation where the foreign corporation has been permitted to raise the defense of usury, even though it could not have done so in the state of its incorporation. $^{60}$

\section{Eminent Domain}

The question whether the right of eminent domain extends to foreign corporations under equal treatment statutes that do not expressly reserve or authorize its exercise ${ }^{67}$ has rarely been considered. In one instance, a foreign corporation without the power to condemn in the state of its origin was extended condemnation rights under a local law made applicable by equal treatment, thus securing rights of domestic corporations to a foreign corporation otherwise limited by charter. ${ }^{68}$ In another, a foreign corporation was permitted to exercise the right of eminent domain, although a dissenting judge, taking an extreme position in the face of clearly manifested legislative intent, would have required an express grant of the right of eminent domain to foreign corporations. $^{69}$ Dearth of precedent permits but an inconclusive appraisal of judicial attitude toward equal treatment in this area. Still, courts that

ot Union Sav. Ass'n v. Cummins, 78 Okla. 265, 19o Pac. 869 (1920). Discriminatory laws have been held to have been repealed by implication with the adoption of equal treatment provisions. Crenshaw v. Texokola Pecan Shellers, Inc., I7 I Tenn. 273, 102 S.W.2d 6o (r937).

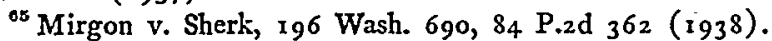

${ }^{\circ 0}$ E. C. Warner Co. v. W. B. Foshay Co., 57 F.2d 656 (8th Cir. 1932). Courts have also construed equal treatment as permitting rules concerning the admissibility of custom and usage to be applicable in a suit on a contract claim, even though the plaintiff-assignee was a foreign corporation having no knowledge of local custom. Park Nat'l Bank v. Goolsby, 179 Tenn. 194, 164 S.W.2d 545 (1942).

or Five equal treatment statutes expressly authorize foreign corporations to exercise rights of eminent domain: IDAHo CODE ANN. $\$$ 30-510 (1948); IOWA CODE ANN. \$ 494.I I (1949); Mont. Rev. Codes ANN. \$ 15-1708 (1955); UTAH Code ANN. $\S$ 16-8-4 (1953); VT. STAT. ANN. tit. $11, \S 762$ (1958) (limited to foreign public service corporations). One state gives equal treatment only as to eminent domain: Ala. CODE ANN. tit. 10, $\S$ r89 (1940). Another, while giving equal treatment, expressly reserves the "power to condemn or appropriate private property": ARK. CONST. art. $12, \S x x$.

${ }^{68}$ Southern Power Co. v. Walker, 89 S.C. 84, 7 r S.E. 356 (rgri).

${ }^{\circ 9}$ Southern III. \& Mo. Bridge Co. v. Stone, I74 Mo. I, 73 S.W. 453 (x903). 
have considered the question are conscious of the fact that according foreign corporations local rights of eminent domain encourages the economic development of the state.

Equal Treatment Statutes and the Pseudo-Foreign Corporation: CoNCLUSION

Finally, this survey of the judicial effect given equal treatment statutes reveals the difficulty courts have encountered, not only in differentiating between foreign corporations and pseudo-foreign corporations, but also in determining the extent to which local corporation law is applicable once the two have been differentiated. ${ }^{70}$ The problems suggesting exploration are presented in the example in which state $A$ denies corporate indemnification of a director adjudged liable for negligence. Assuming state $B$ allows indemnification, the question arises as to whether the nominal state $B$ corporation doing its principal business in state $A$ can indemnify its directors. Should state $A$ deny indemnification because the "internal affairs" of a state $B$ corporation are involved, ${ }^{71}$ or should it pierce the foreign incorporation procedure and decide the question in accordance with local [state $A$ ] law? ${ }^{72}$

The law of foreign corporations has evolved from the rigidity of restrictivism to the equality of a liberalism that has found legislative expression in over half the states. The judicial effect that has been given these equal treatınent provisions has been examined in decisions in significant areas of corporate affairs. Regrettably, little basis has been uncovered for the resolution of the probleins presented by the pseudo-foreign corporation in American corporate law. Further understanding of the meaning of equal treatinent, especially as it is revealed by judicial application, should clarify the legal status of the foreign corporation.

\footnotetext{
${ }^{30}$ An examination of the whole question of the application of local law to corporations essentially local in character but iucorporated in a foreign state, prompted by a recent attempt at legislation specially subjecting pseudo-foreign corporations to certain provisions of local corporation law, appears in Latty, supra note 20.

${ }^{71}$ Cf. Home Inv. Co. v. Fidelity Petroleum Co., 249 S.W. 1109 (Tex. Civ. App. I923).

${ }^{72}$ Cf. Toklan Royalty Corp. v. Tiffany, x93 Okla. 120, I4x P.2d 57x (x943).
} 